\title{
PROFIL PENGGUNAAN OBAT KOMBINASI RISPERIDONE-CLOZAPINE DAN RISPERIDONE DENGAN ANTIPSIKOTIK LAIN PADA PASIEN GANGGUAN MENTAL PSIKOTIK DI RUMAH SAKIT JIWA GRHASIA YOGYAKARTA
}

\author{
Mexsi Mutia Rissa $^{1^{\star}}$, Endang Darmawan ${ }^{1}$, Arum Siwinarni $^{2}$ \\ ${ }^{*}$ Universitas Ahmad Adhalan, Yogyakarta, Indonesia \\ ${ }^{2}$ Rumah Sakit Jiwa Grhasia, Yogyakarta, Indonesia \\ ${ }^{*}$ Correspondence Author \\ Mexsi Mutia Rissa, Universitas Ahmad Dahlan Yogyakarta, \\ Email: mexsi.rissa@gmail.com
}

\begin{abstract}
Abstrak
Sekitar 7\% penduduk Indonesia mengalami gangguan mental psikosis. Daerah Istimewa Yogyakarta merupakan daerah kedua tertinggi tingkat kejadian gangguan mental psikosis dengan angka 10 per 1000 penduduk dan yang dirawat dirumah sakit jiwa dengan gangguan skizofrenia sebanyak $80 \%$. Penatalaksanaan farmakoterapi pada pasien gangguan mental psikotik dengan penggunaan antipsikotik, baik tunggal maupun kombinasi. Antipsikotik diklasifikasikan menjadi antipsikotik atypical dan antipsikotik typical. Kedua kelompok antipsikotik tersebut memiliki aktivitas farmakologi yang sama, yaitu memblokir reseptor dopamine D2. Desain penelitian adalah prospektif. Kriteria inklusi pasien berusia dewasa (18-65 tahun), sedang menjalani rawat inap, mendapatkan terapi antipsikotik risperidon-clozapine dan risperidon dengan antipsikotik lain serta memiliki data yang lengkap. Data didapatkan dari rekam medis serta dianalisis dengan tes univariat untuk menggambarkan distribusi pasien. Pengujian bivariat untuk membandingkan kedua kelompok terapi. Jumlah sampel pada akhir penelitian sebanyak 32 pasien yang terbagi menjadi 2 kelompok antipsikotik antipsikotik risperidon-clozapine dan risperidon dengan antipsikotik lain. Hasil penelitian ini menujukkan bahwa golongan terapi yang sering digunakan adalah kombinasi risperidon-clozapine dibandingkan risperidon dengan antipsikotik lain terhadap pasien gangguan mental psikotik di Rumah Sakit Jiwa Grhasia Yogyakarta.
\end{abstract}

Kata Kunci: Gangguan mental psikotik, Risperidon-clozapine, Risperidon dan antipsikotik lain 


\begin{abstract}
Approximately $7 \%$ of Indonesia's population experience mental disorders psychosis. Yogyakarta Special Region is the second highest incidence of psychotic mental disorders with a rate of 10 per 1000 population and $80 \%$ of those treated in mental hospitals with schizophrenia. Pharmacotherapy management in patients with psychotic mental disorders with the use of antipsychotics, both single and combination. Antipsychotics are classified as atypical antipsychotics and typical antipsychotics. Both groups of antipsychotics have the same pharmacological activity, namely blocking dopamine D2 receptors. The study design is prospective. Inclusion criteria for adult patients (18-65 years), who are inpatient, get risperidonclozapine antipsychotic therapy and risperidone with other antipsychotics and have complete data. Data obtained from medical records and analyzed with univariate tests to describe the distribution of patients. Bivariate testing to compare the two treatment groups. The number of samples at the end of the study were 32 patients who were divided into 2 groups of antipsychotic antipsychotics, risperidone-clozapine and risperidone with other antipsychotics. The results of this study show that the therapeutic group that is often used is the combination of risperidon-clozapine compared to risperidone with other antipsychotics in patients with psychotic mental disorders at Yogyakarta Grhasia Mental Hospital.
\end{abstract}

Keywords: Psychotic mental disorder, Risperidon-clozapine, Risperidone and other antipsychotics

\title{
PENDAHULUAN
}

Kesehatan jiwa merupakan salah satu masalah yang menjadi perhatian dunia saat sekarang, yaitu perubahan pada fungsi jiwa yang menyebabkan adanya gangguan yang menimbulkan penderitaan pada individu atau hambatan dalam melaksanakan peran sosial [1]. Gangguan mental psikosis adalah gangguan kejiwaan berupa hilang kontak dengan kenyataan yaitu penderita kesulitan membedakan hal nyata dengan yang tidak nyata, umumnya akan dimulai dengan kesulitan berkonsentrasi, berbicara tidak jelas dan kesulitan mengingat. Penderita gangguan mental psikosis akan terlihat menyendiri dengan emosi yang datar terkadang secara mendadak emosi menjadi sangat tinggi atau depresi [2]. Penyebab dari gangguan mental psikotik masih belum diketahui. Pasien dengan gangguan personalitas seperti borderline, schizoid, schizotypal atau paranoid qualities dapat berkembang menjadi gejala psikotik. Pada beberapa pasien psikosis juga memiliki riwayat skizofrenia atau gangguan mood [3].

Menurut refrensi [4] tahun 2016 terdapat sekitar 35 juta orang yang mengalami depresi, 60 juta mengidap bipolar, 47,5 juta mengalami dimensia, dan 21 juta mengalami gangguan skizofrenia. Menurut Hasil Riset Kesehatan Dasar [5], gangguan jiwa mengalami peningkatan dengan angka yang signifikan dari 83.612 jiwa menjadi 85.788 jiwa dari tahun 2013 sampai tahun 2018, 1,7 jiwa atau 1-2 orang dari 1,000 warga Indonesia. Jumlah ini cukup besar, artinya 50 juta atau sekitar $25 \%$ dari jumlah penduduk Indonesia mengalami gangguan jiwa.

Penatalaksanaan farmakoterapi pada pasien gangguan mental psikotik dengan penggunaan antipsikotik, baik tunggal maupun kombinasi. Penggunaan terapi 
kombinasi antipsikotik lebih banyak digunakan dibandingkan terapi tunggal yaitu 90,6\% [6]. Penggunaan kombinasi antipsikotik generasi pertama dan antipsikotik generasi kedua merupakan kombinasi yang paling banyak diberikan (70,83\%), karena antipsikotik generasi pertama dapat memperbaiki gejala positif, namun umumnya tidak memperbaiki gejala negatif. Sedangkan antipsikotik generasi kedua dapat memperbaiki gejala positif dan negatif dari skizofrenia dan lebih efektif mengobati pasien yang resisten [7]. Refrensi [8] melaporkan bahwa antipsikotik yang paling sering diresepkan psikiater adalah kombinasi dua obat (typical-atypical) yaitu haloperidolclozapine (42,6\%). Berdasarkan hasil laporan bahwa antipsikotik atypical, yang rata-rata lebih kuat sebagai antagonis $5-\mathrm{HT}$, dapat memiliki efek anti-agresif yang leih baik dari pada obat penghambat D2 yang lebih spesifik [9].

\section{METODOLOGI}

\section{Alat dan Bahan}

Alat yang digunakan pada penelitian ini adalah formulir pengambilan data, digunakan untuk mengumpulkan data demografi pasien, seperti usia, jenis kelamin, status perkawinan, pendidikan, pekerjaan, tanggal masuk rumah sakit hingga tanggal keluar rumah sakit, dan terapi melalui medical record atau rekam medis di Rumah Sakit Jiwa Grhasia Yogyakarta, Indonesia.

\section{Metode pelaksanaan}

Menentukan kelompok sasaran
(populasi penelitian) berdasarkan studi pendahuluan yang telah dilakukan dengan mempertimbangkan beberapa hal. Setiap pasien gangguan mental psikotik yang memenuhi kriteria inklusi pada kelompok penelitian, akan dicatat identitasnya. Subyek selanjutnya dibagi menjadi dua kelompok, yaitu kelompok yang diterapi antipsikotik risperidon-clozapine dan kelompok antipsikotik rispridon dengan antipsikotik lain. Merekap terapi hingga selesai perawatan di Rumah Sakit Jiwa Grhasia Yogyakarta, Indonesia. Melakukan pengolahan dan analisis data secara statistik dengan sistem komputerisasi.

\section{HASIL DAN PEMBAHASAN}

Karakteristik sosio-demografi subyek terhadap diagnosa. Tabel I menggambarkan karakteristik sosio-demografi subyek dalam penelitian ini.

Tabel I. Karakteristik sosio-demografi subyek yang diterapi dengan antipsikotik atypical- atypical dan antipsikotik atypical-typical di Rumah Sakit Jiwa Grhasia Yogyakarta

\begin{tabular}{|c|c|c|}
\hline \multirow[b]{2}{*}{ Karakteristik } & \multicolumn{2}{|c|}{ Frekuensi (n, \%) } \\
\hline & $R-C$ & $\begin{array}{c}R- \\
\text { lainnya }\end{array}$ \\
\hline \multicolumn{3}{|l|}{ Diagnosa } \\
\hline - Skizofrenia & $13(81,2)$ & $\begin{array}{c}13 \\
(81,2)\end{array}$ \\
\hline $\begin{array}{l}\text { - Skizoafektif dan } \\
\text { gangguan afektif } \\
\text { dengan gejala } \\
\text { psikotik }\end{array}$ & $3(18,8)$ & $3(18,8)$ \\
\hline Keterangan: $\mathrm{R}-\mathrm{C}=$ Risperidon- & apine; R-lainn & \\
\hline
\end{tabular}


Tabel I menunjukkan bahwa diagnosa dari data penelitian yang mengalami skizofrenia pada kelompok antipsikotik risperidon-clozapine sama dengan kelompok risperidon dengan antipsikotik lain yaitu 13 subyek $(81,2 \%)$. Sedangkan yang mengalami skizoafektif dan gangguan afektif dengan gejala psikotik pada kelompok antipsikotik risperidon-clozapine dan kelompok antipsikotik risperidon dengan antipsikotik lain yaitu 3 subyek (18,8\%). Terbukti bahwa mayoritas subyek yang digunakan adalah pasien skizofrenia.

\section{Golongan dan jenis obat yang diperoleh pasien gangguan psikotik}

\footnotetext{
Antipsikotik dikelompokkan menjadi dua yaitu antipsikotik golongan pertama/typical dan golongan kedua/atypical yang meliputi banyak obat pada masingmasing golongan, sehingga pilihan untuk praktisi kesehatan dalam memberikan pengobatan. Golongan dan jenis obat yang diterima pasien penting untuk diperhatikan karena akan mempengaruhi kesembuhan pasien serta untuk mengetahui kesesuaian antara keluhan dan diagnosa dengan pengobatan yang diberikan. Table II menunjukan penggunaan antipsikotik berdasarkan golongan kedua kelompok yaitu risperidon-clozapine dan risperidon dengan antipsikotik lainnya.
}

Tabel III. Penggunaan antipsikosis berdasarkan golongan dan jenis obat

\begin{tabular}{|c|c|c|}
\hline Kelompok & $\begin{array}{c}\text { Jenis golongan } \\
\text { obat }\end{array}$ & $N(\%)$ \\
\hline Antipsikotik & Antipsikotik & $16(100)$ \\
\hline Risperidon- & Atypical- & \\
\hline clozapine & atypical & \\
\hline Antipsikotik & Antipsikotik & \\
\hline Risperidon & Atypical- & \\
\hline dengan & Typical & $2(12,5)$ \\
\hline antipsikotik & Risperidon- & \\
\hline \multirow[t]{12}{*}{ lain } & Klorpromazin- & \\
\hline & Trifluoperazin & \\
\hline & Risperidon- & $10(62,5)$ \\
\hline & Haloperidol- & \\
\hline & Clozapine & \\
\hline & Risperidon- & $2(12,5)$ \\
\hline & Trifluoperazin- & \\
\hline & Clozapine & \\
\hline & Risperidon- & $2(12,5)$ \\
\hline & Haloperidol- & \\
\hline & Klorpromazin & \\
\hline & Total & 32 \\
\hline
\end{tabular}

Pada penelitian ini didapatkan data antipsikotik yang diresepkan pada pasien rawat inap di Rumah Sakit Jiwa Grhasia Yogyakarta yang sedang menjalani perawatan yaitu kelompo risperidonclozapine semua subyek mendapatkan terapi yang sama dan pada kelompok risperidon dengan antipsikotik lain 2 subyek (12,5\%) mendapatkan terapi risperidon-klorpromazintrifluoperazin, 2 subyek mendapatkan risperidon-trifluoperazin- 
clozapine, 2 subyek (12,5\%) mendapatkan risperidon-haloperidol-klorpromazin, serta 10 subyek (62,5\%) yang mendapatkan risperidon-haloperidol-clozapine.

Risperidon merupakan obat antipsikotis gerenasi kedua [10]. Obat ini selain bekerja memblok reseptor dopaminergik 2, mengurangi gejala positif dan menstabilan gejala afektif juga bekerja dengan memblok reseptor serotonin 2A, menyebabkan peningkatan pelepasan dopamin di daerah otak tertentu dengan demikian mengurangi efek samping motorik [11]. Efek dari serotonin-antagonis dopamin, menyebabkan output dari dopamin tidak berubah sehingga mengurangi gejala ekstrapiramidal dan juga mencegah peningkatan prolaktin [11]. Walaupun obat ini memiliki efek ekstrapisamidal yang sedikit dibandingkan dengan antipsikotik tipikal [12]. Clozapine, secara umum clozapine bekerja dengan cara yang sama dengan risperidon yaitu mengurangi gejala positif dan menstabilan gejala afektif dengan memblok reseptor serotonin $2 \mathrm{~A}$, menyebabkan peningkatan pelepasan dopamin di daerah otak dan merupakan obat dengan risiko terendah menimbulkan efeksamping gejala ekstrapiramidal.

Haloperidol merupakan derivat butiroferon termasuk antipsikotik golongan pertama. Haloperidol memiliki risiko tinggi terhadap timbulnya gejala ekstrapiramidal. Obat ini selain memblok reseptor dopaminergik 2 sehingga mengurangi gejala positif, agresif, aksplosif, dan perilaku hiperaktif [11], juga menghambat reseptor $\alpha-1$ adrenergik [11]. Klorpromazin, derivat fenotiazin merupakan antipsikotik pertama atau antipsikotik typical. Obat ini bekerja dengan jalan memblok reseptor dopaminergik 2 sehingga mengurangi gejala positif [13]. Selain indikasi sebagai antipsikotik, klorpromazin memperkuat efek analgetik, sehingga membuat pasien lebih acuh tak acuh pada rasa nyeri [14]. Trifluoperazin juga merupakan antipsikotik golongan pertama atau antipsikotik typical yang merupakan derivat fenotiazin, secara umum sama dengan klorpromazin yaitu bekerja memblok reseptor dopaminergik 2 mengurangi gejala psikosis positif [11].

Terapi yang diberikan ke pasien dapat mempengaruhi perubahan gejala fisik terhadap pasien, dari beberapa obat yang digunakan pasien terdapat beberapa interaksi obat berdasarkan level serius yaitu, haloperidol dengan klorpromazin dimana penggunaan bersamaan antara haloperidol dengan klorpromazin menyebabkan keduanya mengalami meningkatkan QTc interval menurut Refrensi[15] yaitu suatu bentuk aritmia jantung terjadi perpenjangan interval QT sehingga dapat menyebabkan takikardi yang dapat berakibat fatal pada pasien bila tidak tertangani [16]. Interaksi yang terjadi secara farmakodinamik dengan efek [15].

Adapun interaksi obat berdasarkan level signifikan yaitu, haloperidol dengan risperidon interaksi yang terjadi berdasarkan mekanisme farmakodinamik dengan efek adisi [11]. Haloperidol digunakan secara bersamaan dengan risperidon menyebabkan 
peningkatan antidopaminergik karena antagonisme aditif dopamine baik dari haloperidol dan risperidon [17], interaksi obat berdasarkan level signifikan lainnya haloperidol dengan clozapine dapat menyebabkan Neuroleptic Malignant Syndrome [15]. Interaksi yang terjadi melalui mekanisme farmakodinamik dengan efek sinergisme [9]. Neuroleptic Malignant Syndrome jarang terjadi tetapi mengancam jiwa, reaksi idiosinkratik pada pengobatan neuroleptik. Neuroleptic Malignant Syndrom dikarakteristikkan dengan demam, kekakuan otot, perubahan status mental dan disfungsi autonomik [18].

Interaksi lainnya antara trifluoperazin dengan risperidon dimana kombinasi keduanya menyebabkan interaksi secara farmakodinamik dengan efek yang ditimbulkan antagonis [11]. Penggunaan secara bersamaan antara trifluoperazin dengan risperidon meyebabkan keduanya meningkatkan QTC interval. Interaksi ini berpotensi membahayakan pasien. Hal ini mengakibatkan penggunaan kedua obat ini perlu mendapatkan perhatian dan dimonitor secara ketat [17]. Trifluoperazin berpengaruh moderat terhadap prolongasi QTc sedangkan risperidon berpengaruh secara severe sehingga kombinasi keduanya berpengaruh signifikan terhadap peningkatan QTc [9].

Adapun penyakit penyerta yang dialami pasien yaitu diabetes mellitus, dimana pasien tersebut juga mendapatkan terapi antidiabetes metformin dan glimepirid. Interaksi antara obat antipsikotik dan obat antidiabetes seperti risperidon dengan metformin dan glimepirid, dimana kombinasi keduanya menyebabkan interaksi secara farmakodinamik dengan efek yang ditimbulkan antagonis [14]. Penggunaan risperidon dengan metformin dan glimepirid bila digunakan secara bersamaan menyebabkan hiperglikemi yang dapat mengubah kontrol glukosa darah, sehingga penggunaannya perlu dimonitoring dengan ketat [17]. Penyebab hiperglikemi karena risperidon mempunyai aksi yang menyebabkan gangguan resistensi insulin seluler dan meningkatkan kadar trigliserida melalui aksinya pada reseptor yang dikenal sebagai reseptor serotonin 5HT-2C, muskarinik-3, dan histamine-1 [14].

Tidak semua interaksi obat bermakna secara klinis. Beberapa interaksi obat secara teoritis mungkin terjadi, sedangkan interaksi obat yang lain harus dihindari kombinasinya atau memerlukan pemantauan yang cermat. Strategi yang dapat dilakukan oleh farmasis untuk mencegah dan menangani interaksi obat menurut Refrensi 19 yaitu: 1) Mencegah kombinasi secara keseluruhan. Kombinasi perlu dihindari apabila risiko yang kemungkinan terjadi lebih besar dari manfaatnya. 2) Penyesuaian dosis obat obyek. Dua obat yang berinteraksi bisa diberikan secara aman selama dosis obyeknya disesuaikan. 3) Memberi jarak waktu pemberian obat untuk mencegah interaksi. 4) Monitoring untuk deteksi dini. Interaksi bisa diatasi dengan monitoring laboratorium secara ketat untuk melihat, evidence based tentang interaksi obat sehingga bisa dilakukan perubahan dosis 
atau penghentian obat jika perlu. 5) Pemberian informasi tentang faktor risiko pasien yang meningkatkan risiko outcome negatif. 6) Perbaikan sistem terkomputerisasi.

\section{KESIMPULAN}

Profil penggunaan terapi kombinasi risperidon-clozapin lebih sering digunakan dibandingkan risperidon dengan antipsikotik lainnya terhadap pasien gangguan mental psikotik di Rumah Sakit Jiwa Grhasia Yogyakartadan

\section{UCAPAN TERIMA KASIH}

Ucapan terimakasih disampaikan kepada Direktorat Riset Universitas Ahmad Dahlan Yogyakarta dan Pendidikan Tinggi untuk skema penelitian pascasarjana tahun 2019, direktur rumah sakit, dokter, perawat, kepala instalasi rekam medis dan farmasis di Rumah Sakit Jiwa Grhasia Yogyakarta yang telah menyediakan fasilitas dan bantuan selama penelitian ini berlangsung. Ucapan terima kasih juga disampaikan kepada semua pasien yang bersedia menjadi subyek dalam penelitian.

\section{DAFTAR PUSTAKA}

1. Keliat, A.B., 2014, Keperawatan Kesehatan Jiwa Kominitas. EGC: Jakarta.

2. Raune, D, Kuipers, E, Bebbington, PE, 2004. Expressed Emotion at FirstEpisode Psychosis: Investigating a Carer Appraisal Model. British Journal of Psychiatry, 184, 321-326
3. Sadock, B.J., Sadock, V.A. \& Ruiz, P., 2015, Kaplan \& Sadock's Synopsis of Psychiatry: Behavioral Sciences/Clinical Psychiatry. 11th penyunt. Philadelphia: Wolters Kluwer.

4. World Health Organization (WHO), 2016, Prevalence of Schyzofrenia Report 2016, Switzerland.

5. Departemen Kesehatan Republik Indonesia., 2018, Riset Kesehatan Dasar (Riskesdas) 2018, Jakarta: Departemen Kesehatan RI.

6. Yulianty, M.D, Noor Cahaya, Valentina Meta, S., 2017, Studi Penggunaan Antispikotik dan Efek Samping Pada Pasien Skizofrenia di Rumah Sakit Jiwa Sambang Lihum Kalimantan Selatan, Program Studi Farmasi Universitas Lambung Mangkurat, Jurnal Sains Farmasi dan Klinis, Vol 03. No 02.

7. Cherrie,G., David, C., Frances, D.,Verity, H., Assen, J., Eóin, K., Jayashri, k., Patrick, McG., Olav, N., Nga, T., 2016, Royal Australian and New Zealand College of Psychiatrists clinical practice guidelines for the management of schizophrenia and related disorders. Australian \& New Zealand Journal of Psychiatry, 50(5), 410-472.

8. Permatasari, V.D., 2016, Pola Penggunaan Antispikotik Pada Pasien Skizofrenia di Instalasi Rawat Inap Rumah Sakit Jiwa Grhasia Yogyakarta Tahun 2014, Skripsi, Universitas Gadjah Mada, 2016, Indonesia. 
9. Chisholm-Burns, M. A. et al., 2016, Pharmacotherapy Principles \& Practice Fourth Edition. New York: McGraw-Hill Education.

10. Bruijnzeel, D., Uma, S., Rajiv, T. 2014. Antipsychotic treatment of schizophrenia: An Update. Asian Journal of Psychiatry, 635 p: $1-5$.

11. Sthal, S.M., 2013, Sthal Essensial Psychopharmacology, Fourth Edition, 79128, Cabridge University Press, New York.

12. Katzung B.G., Masters S.B., et al., 2012, Basic \& Clinical Pharmacology Twelfth Edition. United States: The McGraw-Hill Companies, Inc.

13. Ravanic, D.B., Dejanovic, S.M., Janjic, V., Jovic, S.D., Milovanovic, D.R., Jakovljevic, V., 2009, Effectiveness of clozapine, haloperidol and chlorpromazine in schizophrenia during a five-year period. Arq Neuropsiquiatr; 67(2):195-202. doi: 10.1590/S0004 282X2009000200005.

14. Lacro, J.P., Sanaz Farhadian., et al., 2013, Koda-Kimble \& Young's Applied Therapheutics The Clinical Use Of Drugs 10 Ed. Wolters Kluwer, Philadelphia. 1921-1947.

15. Huang C.L., Hwang T.J., Chen Y.H., Hsieh M.H., Chen H.H., and Hwu H.G., 2015, Intramuscular olanzapine versus intramuscular haloperidol plus lorazepam for the treatment of acute schizophrenia with agitation: An open-label, randomized controlled trial, J Formos Med Assoc,
2015 May; 114 (5): 438-45. doi: 10.1016 / j.jfma.2015.01.018. Epub 2015 Mar 17.

16. Marder S.R., Van Putten T., Schatzberg A.F., Nemeroff C.B., 2015, Antipsychotic medications. The American Psychiatric Press Textbook of Psychopharmacology. Washington, DC: American Psychiatric Press p: 247-261.

17. Medscape., 2019, Drug Interaction Checker, (online), (https://reference.medscape.com/druginteractionchecker), diakses tanggal 6 November 2019.

18. Barbui C, Signoretti A, Mule S, Boso M, Cipriani A., 2018, Does the addition of a second antipsychotic drug improve clozapine treatment?, Schizophr Bull; 35 (2) : 458-68. doi: 10.1093/schbul/sbn030. 19. Syamsudin., 2011, Interaksi Obat Konsep Dasar dan Klinis, Penerbit Universitas Indonesia (UI-Press), Jakarta, Indonesia 